Araștırma Makalesi - Gönderim Tarihi: 24.09.2018 - Kabul Tarihi: 08.10.2018

\title{
Farklı İdeolojik Kimlikler Açısından Sosyal Medyanın Anlam ve Önemi ${ }^{1}$
}

\author{
Saniye Vatandaș ${ }^{2}$
}

\begin{abstract}
Öz
Yeni iletişim teknolojileri, insanlara duygu, düşünce ve ürünlerini başkalarıyla son derece hızlı ve kolay bir şekilde paylaşmalarının imkânlarını sunmaktadır. Sosyal medya bunlardan birisi ve en güncel olanıdır. Sosyal medya, çok kısa sürede günümüz insanının günlük rutinleri arasında kendine yer bulmuş ve her geçen gün daha fazla sayıda insanın kullandığı bir iletişim aracı haline gelmiştir. Özellikle gençler arasında kullanım değeri bakımından hızlı bir yükseliş gösteren sosyal medya, diğer yandan da günümüzün geleneksel medyasına rakip olmakta; hatta kimi zaman tehdit eder duruma gelmektedir. Bu çalışma "sosyal medya" ile "kimlik" ilişkisi hakkındadır. Kimlik en geniş anlamıyla, bireyin tüm özelliklerini kapsamakta; hem kişinin kendisini nasıl gördüğüyle, hem de toplum tarafından nasıl görüldüğüyle ilgilidir. Bu çalışmada, beş farklı ideolojik kimlik üzerinden sosyal medyanın önemi ve anlamı ele alınacaktır. Söz konusu beş kimlik "Sosyal demokrat", "Dindar", "Kemalist", "Milliyetçi" ve "Liberal" kimlikleridir. Araştırma 15-30 yaş grubundaki gençlerle ilgili olup, araştırmanın evreni Türkiye'deki tüm gençlerdir. Tabakalı örnekleme tekniği ile oluşturulmuş örneklem grup 5917 kişiden oluşmaktadır. Anket ile elde edilen veriler SPSS ile analiz edilmiştir. Araştırma sonucunda, bireysel ideolojik kimlikler ile sosyal medyaya ilişkin tutum ve anlayışlar arasında ilişki bulunduğu tespit edilmiştir.
\end{abstract}

Anahtar Sözcükler: Sosyal Medya, İdeolojik Kimlik, Gençlik

Atıf: Vatandaș, Saniye. (2018) Farkı İdeolojik Kimlikler Açısından Sosyal Medyanın Anlam ve Önemi. Akdeniz Üniversitesi Iletișim Fakültesi Dergisi, (AKIL) Kasım (30) s. 418-438

1 Bu çalışma, 1-3 Kasım 2018 tarihleri arasında Akdeniz Üniversitesi Iletişim Fakültesi tarafından düzenlenen 3. Uluslararası Medya Çalışmaları Sempozyumunda sözlü bildiri olarak sunulmuştur.

2 Öğr. Gör., Süleyman Demirel Üniversitesi, İletişim Fakültesi, saniyevatandas@sdu.edu.tr 


\title{
Meaning And Importance of Social Media For Different Ideological Identity
}

\begin{abstract}
Communication technologies are developing rapidly nowadays. This development raise more usage of internet and web tools. One of the most important tool among them is social media. Social media is a new virtual media where users express themselves and stay connected with other users. Social media, which is on a rapid rise especially among youngsters in terms of usage value, seems to be a serious competitor to today's traditional media and even threatens it. This study is about identity relationship and social media. In today's world, "identity" is the most inspiring concept. By identity, characteristic aspects of personality is meant. Five identities in Turkey will be taken in to consideration in this study and the significance of social media will be examined. Five identities are "Social democrat", "Religious", "Kemalist", "Nationalist" and "Liberal". This research is about young people (15-30 years old). The study population consists Turkey and the sample group consists of 5917 people. The data obtained by the questionnaire were analyzed by SPSS. As a result of the research, it has been found that there is a relationship between individual ideological identities and opinions about the importance and meaning of a social media.
\end{abstract}

Keywords: Social Media, Ideological Identity, Youth 


\section{Giriș}

$\mathrm{K}$ imlik, insan bireyini, belirli toplum kesimini veya bir toplumun tamamını işaret eder. Bireyi, toplum kesimini veya toplumu bir anlam sınırı içinde belirler, bu belirleme işlemi sırasında hem birleştirir ve hem de ayırır. Tanım kapsamında olan veya olması istenenleri birleştirirken, tanımın kapsamında olmayan veya olmaması gerekenleri ise ayırıp, ötekileştirir. Birçok kimlik vardır; öznenin konu edinilen özelliğine göre kimliklerin anlam alanları ve nitelikleri de farklılaşmaktadır. Örneğin bireylerin cinsiyetlerini eksene alan ve cinsiyet ekseninde toplumsal konum ve rollerini belirleyen toplumsal cinsiyet kimlikleri vardır. Bireylerin sosyo-ekonomik imkân ve durumlarını temel alan "yoksul", "zengin", "sosyete", "burjuva" gibi kimlikleri vardır. Bireylerin dini inançlarını konu edinen kimlikler vardır; "Müslüman", "Hristiyan", "Budist"... gibi. Veya bireylerin veya toplum kesimlerin olay ve olgularını algılayış ve anlayış biçimlerini, eşyaya ve hayat bakış tarzlarını ifade eden kimlikler vardır; "Sosyal Demokrat", "Milliyetçi”, "Kemalist” gibi. Bu her bir kimlik öznesinin yol haritası işlevini görür; olay ve olgular karşısındaki durumunu belirler. Sosyal medya ise günümüz dünyasının en önemli olgularından birisidir. Bilgi edinme, eğlenme, iletişim kurma, veri depolama, resmi veya resmi olmayan biçimiyle işlemler yapma gibi birçok işlevi yerine getiren sosyal medya gündelik hayatın en önemli unsurlarından birisi olmuş bulunuyor. Bu makalede belirlenmiş bazı ideolojik kimlikler ile sosyal medyanın anlam ve önemine ilişkin tutum ve anlayışlar incelenecektir. Buna geçmeden önce konunun dayanakları olan "Kimlik", "İdeoloji” ve "Sosyal Medya" üzerine birkaç bir şey söylemek, konunun anlaşılmasına katkısı açısından yararlı olacaktır.

\section{Temel Kavramlar}

\section{1. Kimlik}

Kimlik bir tanımlamadır. Her kimlik, "kim?" sorusu üzerinden öznesini tanımlar. Bu tanımlama aşamasında öznesinin "ne olduğunu" ve "ne olmadığını" ifade eder. Dolayısıyla her kimlik tanımlama işlemini "aynılık" ve aynı zamanda "farklılık" ekseninde gerçekleştirir. Bir yandan öznesinin tanım kapsamında yer alan özelliklerini bir araya getirip, anlamlı bir bütün olarak ifade ederken; diğer yandan da farklılıklar üzerinden öznesini "ötekilerden" ayırır. Bu ayırma işlemini ise öznesinin "ne olmadığını" ifade ederek yapar (Vatandaş, 2010: 13-15).

Kimliğin ne olduğunu ve ne tür bir işlev yerine getirdiğini birey üzerinden açıklamak gerekirse; her birey, kimliği aracılığıyla, kimliğinin tanımladığı ve dile getirdiği anlam alanı bağlamında öteki öznelerden farklı bir özne olarak var olduğunu ifade eder. "Bir bireyi tüm özellik ve nitelikleriyle tanımlayacak bir kimlik, dolayısıyla tanımlama var mıdır?" sorusunun cevabı oldukça ciddi tartışmaların açığa çıkmasına sebep olabilecek nitelikte bir sorudur. Bu alana girmeden ifade etmek gerekirse; her kimlik öznesini bir yönüyle ele alır ve tanımlar. Söz konusu yön, kimliğin anlam alanını teşkil eder. Her kimliğin ise birbirinden farklı anlam alanları vardır. Zaten kimlikler söz konusu anlam alanlarını ifade etmek için vardırlar. Dolayısıyla her öznenin birçok kimliği 
vardır. Fakat bu istisnalar bir yana herhangi bir şekilde de olsa karışıklığa yol açmaz. Esasen yol açmaması beklenir. Eğer bir karışıklık oluşmuşsa tanımlarda bir karışıklık olduğu düşünülür. Anlam sınırı açık ve dolayısıyla öznesini belirli özellikler ve ölçüler bağlamında doğru tanımlayan her kimlik, normal şartlarda birbirinden farklı düzlemde yer alır. Bu ise kimliklerin birbirleriyle çatışmasını önler. Bu durumu örneklendirmek gerekirse bireyin cinsiyeti açısından "erkek", mesleği açısından "memur", mesleğinin sahip olduğu hiyerarşi açısından "şef", yaşı açısından "genç", medeni durumu açısından "evli", dini/inancı açısından "Müslüman", etnik kökeni açısından "Türk" olması böyle bir şeydir. Dikkat edilirse bu kimliklerin hiç biri diğeriyle çatışmamaktadır. Hepsi aynı özneyi ifade etmektedir. Bu kimlikler bazen birbirini kapsayacak şekilde dikey bir anlam çizgisi üzerinde sıralanırken, bazen de yatay olarak ve birbirinden bağımsız olarak sıralanırlar.

Kimliğin en önemli işlevlerinden birisi, öznesini olay ve olgular karşısında konumlandırmasıdır. Kimlik, öznesini tanımlarken, esasen ifade edilen anlam alanı kapsamında öznesinin olgu ve olaylar karşısında olan veya olması gereken durum ve duruşunu belirler. Olaylar ve olgular karşısında bireyin veya toplum kesimlerinin tutum ve davranışları açısından bir yol haritası işlevi gören, bireyin veya toplum kesimlerinin durum ve gidişatlarını şekillendiren, bireylerin ve toplum kesimlerinin istikametlerini belirleyen kimlikler, bu gerçekleştirdikleriyle de öznelerini standardize ederler. Zira her kimliğin bir standardı vardır ve öznesinden bu standarda göre konumlanmasını, davranmasını veya tavır sergilemesini ister. İdeolojik kimlikler bunun tipik örneğidir. Dolayısıyla bireyin hal ve hareketlerinden, tutum ve davranışlarından, inanç ve düşüncelerinden hareketle mensubu olduğu kimlik veya kimlikleri; kimlikten hareketle de bireyin durum ve gidişatını anlamak ve olay ve olgular karşısından muhtemel tutum ve davranışlarını öngörmek mümkündür. Bu durumu örneklendirmek için kullanımı her geçen gün daha da yaygınlaşan, neredeyse bireysel ve toplumsal her şeyle irtibatlı hale gelen, olay ve olguları anlamlandıran ve hatta şekillendiren, adeta yaşam tarzlarının en önemli referanslarından birisi durumuna ulaşan sosyal medya dikkate alınabilir. Öznesinin olay ve olgular karşısındaki durum ve duruşunu belirleyen ideolojik karakterli bireysel kimliklerin, sosyal medyanın önem ve anlamının bireyler tarafından kavranış şeklini etkilemesi beklenir.

\section{2. İdeoloji}

İdeoloji, modern dönemin en önemli kavramlarında birisidir. Tarihi, çoğu zaman zannedildiğinin aksine, oldukça yenidir. Modern zamanların kavramıdır. İdeolojiye yüklenen anlamlar tarih içinde farklı mecralardan geçerek belli tanım ve kavramlaştırmalara ulaşmıştır. İdeoloji sözcüğü ilk olarak 18. yüzyılın sonlarında Fransız filozof Destutt de Tracy (1754-1836) tarafından "düşünceyi inceleyen bilim" olarak; metafizik karşıtı bir düşünce biliminin adı olarak kullanılmıştır. (Özbek, 2011: 32). Daha sonra ideoloji konusunda tarihsel süreç içerisinde farklı düşünürler tarafından farklı tanımlar yapılmıştır. Bu tanımlardan bazıları şunlardır: Toplumsal yaşamdaki anlam, gösterge ve değerlerin üretim süreci; belli bir toplumsal grup veya sınıfa ait fikirler kümesi veya inanç sistemi; egemen bir siyasi iktidarı meşrulaştırmaya yarayan 
fikirler; sistemli bir biçimde çarpıtılmış iletişim; yanlı bilgi; söylem ve iktidarın çatışması ve benzerleri. Klasik yaklaşımın bir başka ve özellikle siyasal bilim açısından yapılmış tanımına göre ideoloji kitle toplumunun ortaya çıkmasıyla beliren inançlar kümesidir. $\mathrm{Bu}$ inanç ve tutumları bir kişinin, bir kümenin düşünsel sınırlarına indirgemek yanlıştır. Hatta onları kişiselleştirmek de pek doğru değildir. İdeoloji, yönetilenler arasında yaygın, yönlenmiş; fakat sınırlı ve belirsiz fikir kümesidir. Bir başka değerlendirmeye göre ideoloji, olaylar üzerine kurulu, insanların düşünce ve davranışlarını etkileyen çeşitli kaynaklardan beslenen bir inanç sistemidir. Maddi olaylar yanında düşünsel olaylar da ideolojiyi etkiler, ona yön çizer. Kimi kez bu etkileme son derece yoğundur. Toplumsal sistemin öğeleri arasında yoğun bir etkileşim söz konusu olabilir. Yine klasik anlayış içinde kalarak yapılmış bir tanıma göre ideoloji, insan eyleminin amacını, bu amaçlara nasıl varılacağını tanımlayan ve sosyal ve fiziki gerçekliğin niteliğini belirleyen bir değerlendirici ilkeler sistemidir. İdeolojinin geleneksel olarak üç temel kullanımı olduğu söylenir. Bunlardan ilki, belirli bir sınıf ya da gruba özgü inançlar sistemi olmasıdır.

İkincisi, doğru ya da bilimsel bilgiyle çelişebilecek aldatıcı inançlar sistemi yani yanlış fikirler içermesidir. Üçüncüsü ise anlam ve fikir üretiminin genel süreci olmasıdır. İdeoloji teriminin bu denli değişken, farklı ve çok anlamının olmasına Foucault bir açıklama getirmiştir. Ona göre bu durumun sebebi ideolojinin hermenötik (yorumsama) bağıdır. Bu bağ itibariyle ideoloji, farklı birey, toplum ve düşünce adamına göre değişmekte ve farklı özellikleriyle ele alınmaktadır. Foucault'a göre ideoloji, hakikat karşısında sahte olanı, daha doğrusu kurgulanmış olanı göstermektir. (Purvis, 2014).

İdeoloji sözcüğünü siyaset, toplum, tarih felsefesi ve ekonomik ilişkileri açıklamada en başarılı şekilde kullanan isim hiç kuşkusuz Karl Marx olmuştur. Marx, ideoloji sözcüğünü önce olumsuz, daha sonraları olumlu anlamda kullanmıştır. İlk dönem tanımlamalarına göre ideoloji, gerçeğin baş aşağı edilmiş, dolayısıyla sakatlanmış ve eğri büğrü hale getirilmiş bir görünümüdür. İnsanlar ve onların sorunları, fiziki sürecin bir sonu olarak retina üzerinde görüntünün baş aşağı olması gibi, hayati bir sürecin sonu olarak baş aşağıdır. İlerleyen dönemlerde Marx, her ideoloji için bu durumun yaşanacağını kabul etmemiş, hatta her ideolojinin yanlış olacağına dair önermenin yanlış olacağını savunmuştur. (Outhwaite, William, 2008:349; Mardin, 1982:31) Bunu dile getirirken de bir başka ve yeni bir ideolojinin sözcülüğünü yapmıştır. Ona göre artık ontolojik kader yerine tarihi maddecilik vardır. Tarihi maddecilik, tasavvur, bilinç ve hayallerden hareket eden spekülasyonlara son vermektedir ve verecektir.

İdeoloji tanımları kendi içinde çeşitli gruplandırmalara tabi tutulabilir; olumlu-olumsuz tanımlar, yumuşak-sert tanımlar, zorlayıcı-ikna edici tanımlar gibi. Marx, ideolojiyi olumlu-olumsuz tanımlar ekseninde anlamlandırırken, Lefebvre ideolojilerin, zorlayarak ve ikna yoluyla kendini kabul ettirmeye veya müdahalede bulunmaya çalıştığını ifade etmiştir (Kazancı, 2013). Konuyu özel bir çalışmasının konusu yapan bilim insanlarımızdan Şerif Mardin ise ideolojiyi yumuşak-sert ideoloji olarak iki formda ele almış ve sert ideolojinin sistematik bir şekilde işlenmiş, temel teorik eserlere dayanan, seçkinlerin kültürüyle sınırlandırılmış, muhtevası kuvvetli bir yapıyı kast ettiğini, yumuşak ideolojinin ise kitlelerin çok daha şekilsiz inanç ve bilişsel sistemlerine 
atıfta bulunduğunu, dinin yumuşak ideoloji için bir fırsat oluşturabileceğini ifade etmiştir (Mardin, 1982). Batıda sosyal bilimciler dini modern dönemlerde kişilik billurlaştırıcı ve endişe azaltıcı olarak kullanmışlardır. Bu haliyle din yumuşak bir ideoloji olarak değerlendirilmiştir. Mardin, bu ayrımı açıklamak için "vaziyet alışlar" olarak üçüncü bir kavram üretmiştir. Ona göre vaziyet alışlar, ideolojiler gibi insan eylemine yön veren yapılardır. Her insan belirli olaylar karşısında belirli tutumlar içerisine girer ve bunun bilimsel olarak incelenmesi vaziyet alışların alanıdır. Vaziyet alışlar ile ideolojilerin ilişkisi ise vaziyet alışların da ideolojiler gibi toplum olayları için bir anlam ekseni sağlamasıdır.

İdeoloji ayrıca söylem, argüman, imaj ve basmakalıp yargı gibi belli bir amaca hizmet eden ve belli grup veya aktörler tarafından yönetilen bir dizi sembolik temsiller olarak da görülebilir. Bu kategoriye "izm" olarak ifade edebileceğimiz Liberalizm, Faşizm, Komünizm, Anarşizm ve Marksizm, Leninizm, Maoizm, Stalinizm ile belli ekoller, doktrinler -Truman Doktrini, Monroe Doktrini, Chicago Okulu, Frankfurt Okulugirmektedir. Ayrıca "muhafazakâr", "ilerici" ve "ırkçı" gibi bir politik sistem içindeki belli duruşlar da bu kategoriye dâhil edilebilir. Bu ideolojiler kendilerine bağlı aktörleri karakterize ederler. Örneğin, Liberal bir birey bu ideolojiye sahiptir, Sosyalist olarak tarif edilen kişi sosyalist dünya görüşüne bağlıdır. Bu kategorideki ideoloji anlayışı partizanlığı ve görüşleri temsil etmektedir.

\subsection{Sosyal Medya}

Hızla gelişen iletişim teknolojileri, bireylerin toplumsal yaşantısını son derece hızıı bir şekilde değiştirmektedir. Bu açıdan günümüzde en yaygın kullanılan iletişim araçlarından birisi durumundaki sosyal medya oldukça önemlidir. Her kesimden hemen herkesin sıklıkla ifade ettiği üzere, sosyal medya bugünün dünyasında bireylerin, ekonomik, siyasi ve kültürel anlayışları ve yaşantıları üzerinde güçlü etkilere sahip durumdadır. Gün içinde giyilen kıyafetlerden, gidilecek mekânların seçimine kadar pek çok şey, sosyal medya aracılığıyla gerçekleştirilmektedir. Siyasi veya kültürel faaliyetler sosyal medya aracılığıyla organize edilmekte ve uygulamaya aktarılmaktadır.

Tanışmalar, yeni arkadaşııklar ve hatta evlilikler bile sosyal medyanın etki alanında gerçekleşmektedir. Boşanma davalarında sosyal medyanın etkisi haberlerin sıklıkla konularından birisi olarak karşımıza çıkmaktadır. İnsanlar duygu ve düşüncelerini sosyal medya ile şekillendirmekte ve sosyal medya üzerinden paylaşmaktalar. Sosyal medya kapsamında anlam kazanan yeni iletişim platformları, öğrencilerin ödev yapma alışkanlıklarından kitap okuma alışkanlıklarına, serbest zaman değerlendirme alışkanlıklarından arkadaşlarla olan iletişim biçimlerine kadar gündelik yaşantıya ait ne varsa neredeyse hepsini değişime ve dönüşüme uğratmış durumda. Bu sebepledir ki Manuel Castells, üstelik görece erken sayılabilecek bir zaman diliminde, bilgi çağının yeni dinamikleriyle şekillenen toplumu "Ağ Toplumu" olarak adlandırmıştır (Castells, 2013). Kitle iletişim araçlarının kullanımının toplum içinde hızlı bir şekilde yayılarak dünyanın küresel bir köye dönüşeceğini dile getiren Mc Luhan 'Araçlarımıza biçim veririz, ardından araçlarımız bize biçim verir" derken, sosyal medyanın işlev 
ve etkilerine işaret etmiş gibidir. Günümüzde birbirine internet aracılığıyla bağlı olan bireyler, ulaşılabilirliği, ekonomikliği, kullanım kolaylığı ve zaman kavramının olmaması gibi sebeplerden dolayı hem sosyal medya araçlarına yön veren, hem de bu araçlardan etkilenen konuma erişmiş bulunuyorlar (Vatandaş, 2015).

Sosyal medya tüm dijital platformları kapsayan bir tanım olarak kullanıldığı kadar, belirli sosyal ağ siteleri için de kullanılmaktadır. Çoklu iletişimi mümkün kılan sosyal medya, teknoloji ile desteklenen belli bir ağ bağlantısını kullanan kullanıcılara içerik paylaşma imkânı yaratan bir platformdur. Sosyal medya, kullanıcıların kendi profillerini yaratıp, mevcut ilişkilerinden oluşturdukları kişi gruplarıyla paylaşım içinde oldukları ve diğer kullanıcıların profillerini de izleyebildikleri sanal platformlardır. Sosyal medya, ilişki kurma, güven inşa etme, diğer insanlara ulaşma ve onlarla bağlantılı kalmada etkili bir iletişim sürecinin ve bununla ilgili bilişim teknolojilerinin kullanılması ile ilgili olup (Safko, 2010: 4), bir takım temel özelliklere sahiptir. Bu özellikleri ise şu şekilde sıralamak mümkündür:

Katılım: Sosyal medya, kendisine ilgili ve istekli olan herkesi "sosyalleşme" sürecine katkı yapma konusunda oldukça üst düzeyde cesaretlendirmektedir. Bu da yaygın olarak bilinen anlam ve olgusal boyutlarıyla birbirinden ayrı olan medya ile kitle arasındaki farklıı̆̆ın kaybolmasına, yani "içerik oluşturan" ve "takip eden" ayrışmasının azalıp, neredeyse aynılaşmasına yol açmaktadır.

Açıklık: Sosyal medya servislerinin birçoğu geri bildirim ve katılıma son derece açıktır. İçeriğe ulaşmada ve içeriği kullanmada nadiren giriş engelleri bulunmaktadır. Zaten, şifre korunaklı içerikler de kullanıcılar tarafından pek ilgi görmemektedir. Bu ise katılma, eleştirme, yorumlama ve bilgi paylaşımı durumlarının teşvik görmesini sağlamaktadır.

Karşılıklı iletişim: Geleneksel medyada içerik bir kaynaktan izleyicilere dağıtılıyordu. Sosyal medyada ise durum tamamen değişmiş bulunuyor. Sosyal medya, baskın bir özellik olarak iki yönlü bir iletişim ve etkileşim sağlamaktadır.

Topluluk: Sosyal medya, farklı kulvarlarda ve farklı amaçlar etrafında farklı toplulukların oldukça hızlı bir şekilde oluşmasına ve etkili bir iletişime sahip olmasına imkân sağlamaktadır. Topluluklar, sosyal medya aracılığıyla, ortak ilgileri kapsamında, kolaylıkla ve yaygın bir iletişim sürecine dâhil olmaktadırlar.

Bağlantılı olma: Sosyal medya sitelerinin birçoğu, başka sitelerle ve net ortamlarıyla bağlantılı olma durumlarına imkân sağlamakta veya mevcut bağlantıları geliştirmekte ve diğer sitelere, kaynaklara, kişilere link vererek iletişim yoğunluğunu artırmaktadır.

Sosyal medya, çok kısa sürede günümüz insanının günlük rutinleri arasında kendine güçlü bir yer bulmuş ve her geçen gün daha fazla sayıda insanın kullandığı bir iletişim aracı haline gelmiş durumdadır. Sosyal medya, içerik üretimi, yayınlama ve ulaşma konularında kuralları büyük oranda yeniden yazmış bulunuyor. Basitçe bir tespitle ifade etmek gerekirse, medya platformunu çoktan çoğa olarak değiştiren 
yeni bir paradigma olarak tanımlanabilecek sosyal medya (Poytner, 2010: 160), en iyi geleneksel medya bağlamında açıklanabilmektedir (Zarella, 2010: 13). Çünkü isminde "medya" sözcüğü olmasına rağmen "sosyal medya" geleneksel medyadan farklı özelliklere sahiptir. Özgünlüğünü oluşturan en önemli farklılığı ise, herhangi bir kişinin içeriği oluşturabilmesi, yorumda bulunabilmesi ve katkı sağlayabilmesi şeklinde açıklanabilir (Scott, 2010: 38). Geleneksel medyanın önemli unsurlarından televizyon, dergi, gazete ve radyo gibi medya araçları tek yönlü ve statik yayın teknolojilerine sahiptiler.

İzleyicinin, bu yayınlarda beğenmediği veya onaylamadığı içeriklere anında ve etkili bir geri bildirimde bulunması mümkün değildi; halâ da öyledir. Yeni web teknolojileri ise herkesin kolayca içerik oluşturmasına ve daha önemlisi bu içeriği yayınlamasına ve dağıtmasına izin vermektedir. Bu durumda, insanlar bu yeni ortamlarda sosyal ve çift yönlü bir iletişim platformuna kavuşmuş olmaktadır.

Sosyal medya olarak adlandırılan sanal ortam, kullanıcı tabanlı olmasının yanında kitleleri ve insanları bir araya getirmesi ve aralarındaki etkileşimi arttırması bakımından büyük önem taşımaktadır. Yapılan araştırmalar insanların, bu sanal gerçeklik içinde gün geçtikçe daha fazla vakit harcadıklarını, bu sanal gerçeklik içinde gerçek yaşam intiyaçlarını karşılamaya çalıştıklarını ve yine bu sanal gerçeklik içinde adeta yeni bir yaşam alanı inşa etiklerini göstermektedir. Fakat bu da bazı önemli sayılabilecek problemlere yol açabilmektedir. Problemlerin en önemli sebebi ise, kimi zaman sanal dünyayla gerçek dünya arasındaki sınırın belirsizleşmesiyle ilgilidir. Öyle ki sanal dünyada arkadaş bulma, bu dünyadaki insanlarla sosyal ve siyasi düşünce alışverişinde bulunma; hatta bu dünyadan birileriyle tanışıp evlenme gibi ciddi kararlar alınabilmektedir. Bu ise gerçek dünyada niteliği ve şekli birçok bakımdan tartışmalara açık ilişki ve irtibatların oluşmasına yol açmaktadır.

Sosyal medyada ilişkiler sanal, ancak bireysel veya toplumsal düzlemde yaşanan problemler gerçektir. İşte bu sanallık-gerçeklik farklılığı birbiriyle örtüşmeyen veya iç tutarlıı̆̆ı problemli anlayışlara, tutum ve tavırlara, davranışlara, yaşam tecrübelerine yol açmaktadır. Özellikle gençler arasında kullanım değeri bakımından hızı bir yükseliş gösteren sosyal medya, kullanıcıları için başlı başına bir yaşam alanı oluştururken, oradaki ilişki ve iletişimler ise gerçek dünyadakilerle birçok bakımdan çelişen yaşam anlayışlarının oluşmasına yol açmaktadır. Özetle, bugün itibarıyla gelinen aşamada bireyler sosyal medyanın hem öznesi ve hem de nesnesi konumundadırlar.

\section{Araștırmanın Yöntemi ve Katılımcıların Bazı Özellikleri}

Açılımı "Sosyal ve Ekonomik Araştırmalar Merkezi" olan SEKAM, ilk kez 2012 yılında gerçekleştirip bulgularını bilim insanlarıyla ve kamuoyu ile paylaştığı, incelenen olgudaki muhtemel değişimi tespit edebilmek için her 5 yılda tekrarlamayı planladığı Türkiye'de Gençlik (Gençliğin Özellikleri, Sorunları, Kimlikleri ve Beklentileri) başlıklı araştırmanın Nisan-Haziran 2017 tarihinde ikinci kez tekrarlanmasıyla elde edilen 
veriler, bu makalenin istatistiksel kaynağını teşkil etmektedir ${ }^{3}$. Araştırmanın evrenini Türkiye'de yaşamakta olan 15-30 yaş grubundaki gençler oluşturmaktadır. Bu evreni temsil özelliğine sahip örneklem tespiti için katmanlı tesadüfi örneklem tekniği tercih edilmiştir. Türkiye evrenini temsil kabiliyetine sahip örneklem belirlemek için Türkiye İstatistik Kurumu'nun (TUIK) belirlediği ve araştırmalarında kullandığı 12 bölge tasnifi kullanıımıştır. Araştırmanın veri toplama aracı olan anket, araştırmanın evrenini temsilen seçilen 81 şehirde ve demografik ölçekte şehir kategorisine dâhil edilebilecek ilçeler dâhil 156 kentsel, 197 kırsal olmak üzere toplam 353 yerleşim biriminde 5917 kişiye uygulanmıştır.

Anket, örneklem guruba dâhil bireylerle birebir uygulanmıştır. Araştırma nicel karakterde bir alan araştırması olup, nesnesini tanımlayıcı niteliktedir. Araştırma nesnesini tanımlama amacında olduğu, bir diğer ifadeyle "ne" sorusuna cevap arayışı içerisinde olduğu için, araştırmanın test edilecek hipotezleri bulunmamaktadır.

Araştırmanın elde edilen bulguları değerlendirilirken, istatistiksel analizler için SPSS18 programı kullanılmıştır. Verilere ilişkin korelasyon ve frekans analizi yapılmış, buna ilaveten verilerin ortalama ve standart sapmaları dikkate alınmıştır. Böylelikle değişkenler arasında ilişki bulunup-bulunmadığı, eğer ilişki var ise bu ilişkinin gücünün ve yönünün ne olduğu, ayrıca tercihlerin odak noktası ile tercihlerdeki değişim aralığı belirlenmeye çalışılmıştır.

Araştırmanın katılımcılarının olgusal özellikleri hakkındaki bazı bilgileri ifade etmek gerekirse; Araştırmada TUIK'in geliştirdiği 12 bölge ölçeği esas alınmış, örneklem grubun bölgelerdeki oranı ile bölge nüfusunun genel nüfusa oranı arasındaki ilişki korunmaya çalışılmıştır (Tablo-1). Araştırmaya katılanların \%55,1'i Kadın, \%44,9'u Erkek'tir (Tablo-2).

Öğrenim düzeyinde katılımcıların mezuniyetleri esas alınmıştır. Böylelikle ilkokul mezunundan doktora yapmışına kadar her öğrenim düzeyindeki katılımcıdan veri elde etme imkânı olmuştur (Tablo-3).

Araştırma ile 15-30 yaş grubunda yer alan herkese anket uygulanmış ve bireylerin yaşları SPSS'e girerken aynen korunmuş fakat daha sonra istatistiksel açıdan ilişkilerin anlamlılık durumunu riske etmemek için yaşlar gruplanarak dört kategoriye indirgenmiştir (Tablo- 4).

Katılımcıların doğdukları, halen yaşadıkları ve yaşamları boyu en çok yaşadıkları yerleşim merkezinin kır veya kent olup-olmama durumu, medeni hal, çalışıyor olupolmama durumu, lise veya üstü öğrenime sahip olanların öğrenim alanlarının niteliği katılımcıların belirlenmesinde dikkate alınan olgusal özellikler olarak anlam kazanmıştır.

3 Araştırma ekibinde yer aldığımız söz konusu araştırmanın bazı verilerini kullanma SEKAM'ın yazıı izni ile gerçekleşmiştir. 
Tablo-1: Araşıtırmanın Yürütüldüğü Bölgeler

\begin{tabular}{|c|c|c|}
\hline & Katımcı Sayısı & $\%$ \\
\hline İstanbul & 767 & 13,0 \\
\hline Batı Marmara & 450 & 7,6 \\
\hline Ege & 523 & 8,8 \\
\hline Doğu Marmara & 248 & 4,2 \\
\hline Batı Anadolu & 422 & 7,1 \\
\hline Akdeniz & 644 & 10,9 \\
\hline Orta Anadolu & 384 & 6,5 \\
\hline Batı Karadeniz & 573 & 9,7 \\
\hline Doğu Karadeniz & 731 & 12,4 \\
\hline Kuzeydoğu Anadolu & 297 & 5,0 \\
\hline Ortadoğu Anadolu & 416 & 7,0 \\
\hline Güneydoğu Anadolu & 462 & 7,8 \\
\hline Toplam & 5917 & 100,0 \\
\hline
\end{tabular}

Tablo-2: Katılımcıların Cinsiyetleri

\begin{tabular}{|c|c|c|}
\hline Cinsiyet & SAYI & $\%$ \\
\hline Erkek & 3259 & 55,1 \\
\hline Kadın & 2658 & 44,9 \\
\hline Toplam & 5917 & 100,0 \\
\hline
\end{tabular}

Tablo-3: Katılımcıların Öğrenim Düzeyleri

\begin{tabular}{|c|c|c|}
\hline & SAYI & $\%$ \\
\hline İlköğretim & 240 & 4,1 \\
\hline Lise & 1750 & 29,6 \\
\hline Ön lisans & 1329 & 22,5 \\
\hline Lisans & 2460 & 41,6 \\
\hline Lisansüstü & 138 & 2,3 \\
\hline Toplam & 5917 & 100,0 \\
\hline
\end{tabular}


Tablo-4: Katılımcıların Yaşları

\begin{tabular}{|c|c|c|}
\hline & SAYI & $\%$ \\
\hline $15-18$ yaș & 941 & 15,9 \\
\hline $19-22$ yaș & 2422 & 40,9 \\
\hline $23-25$ yaș & 1231 & 20,8 \\
\hline $26-30$ yaș & 1323 & 22,4 \\
\hline Toplam & 5917 & 100,0 \\
\hline
\end{tabular}

\section{Araștırmanın Bulguları}

Araştırmanın değişkenleri iki grupta ele alınabilir: 1- İdeolojik kimlikler, 2-Sosyal medyaya ilişkin tutum ve görüşler. Araştırmanın bu değişkenlerden kimliklerle ilgili genel bulguları frekans değerleri itibarıyla dikkate alınacak olursa (Tablo-5): Söz konusu beş ideolojik kimlikten (Liberal, Sosyal Demokrat, Dindar, Kemalist, Milliyetçi) "Bana çok uygun" düzeyinde kabullenilen kimliğin \%39,1'lik oranıyla "Milliyetçi" kimliği olduğu görülmektedir. "Milliyetçi” kimliğini \%29,1'lik oranıyla "Dindar" kimliği takip etmektedir. Bundan hareketle gençlerin ağırlıklı olarak "Milliyetçi-Dindar" çizgisinde bir konumu benimsedikleri ifade edilebilir. Bu tespitimizi güçlendirmesi açısından "Bana uygun" seçeneği önemli bir referanstır. Zira "Bana uygun" düzeyinde olmak üzere "Milliyetçi" kimliğinin \%37,8, "Dindar" kimliğinin ise \%43,3 oranında kabullenildiği tespit edilmiştir.

Kimliklerin kabullenilmesindeki "Bana çok uygun" ve "Bana uygun" seçeneklerini birleştirerek ifade etmek gerekirse "Milliyetçi" kimliği \%76,9'luk bir oranla, "Dindar" kimliği ise \%72,4'lk bir oranla kabullenilmektedir. Bu sıralamanın 3. aşamasında \%59,1'lik oranla "Sosyal Demokrat" kimliği yer almaktadır. Söz konusu beş kimlik arasında gençler tarafından en düşük düzeyde kabullenilen "Liberal" (\%27) kimliğidir. "Kemalist" kimliği ise arada (\%31) yer almaktadır.

Araştırmanın ideolojik kimliklerin kabullenilme veya kabullenilmeme durumlarıyla ilgili verileri, ortalama $(X)$ ve standart sapma $(S)$ değerleri dikkate alınarak analiz edilecek olursa; "Liberal" kimliğinin görece daha homojen bir dağılım gösterdiği, ortalamasının ise "Bana uygun değil" ile "Bana hiç uygun değil" seçeneklerinin yaklaşık ortasında yer aldığı, standart sapması da dikkate alındığında dağılımının "Bana uygun değil" ile "Bana hiç uygun değil" cevaplarını kapsadığı anlaşılmaktadır. Bu durum genel anlamda "Liberal" kimliğinin gençler tarafından kabullenilmediği anlamına gelmektedir. Buna karşılık, ortalama değeri açısından, kimliklerle ilgili diğer tüm seçenekler dikkate alındığında, en ayrı bir konumda duran "Milliyetçi" kimliğidir.

"Milliyetçi" kimliğinin ortalaması 1,97 olup bu değer "Bana çok uygun" ve "Bana uygun" seçeneklerinin ortasını işaret etmektedir. Standart sapma değeri dikkate alındığında "Milliyetçi" kimliğini kabul dağılımının "Bana çok uygun" ile "Bana uygun" cevaplarını kapsadığı anlaşılmaktadır. Bu ise genel anlamda "Milliyetçi" kimliğinin gençler 
tarafından kabullenildiği anlamına gelmektedir. Benzer durum "Dindar" kimliğinde de gözlenmektedir. "Sosyal Demokrat" kimliği ise gençler tarafından kabullenilmekabullenilmeme durumları açısından görece en yüksek düzeyde belirsizliğe sahip bir kimlik olarak anlam kazanmaktadır. Zira "Sosyal Demokrat" kimliğinin ortalaması "Bana uygun değil” ile örtüşmekle birlikte, standart sapma değeri dikkate alındığında ağırlık noktasının kısmen "Bana uygun" durumunu da işaretlediği anlaşılmaktadır.

Tablo-5: İdeolojik Kimliklerin Kabullenilme Durumu

\begin{tabular}{|c|c|c|c|c|c|c|c|}
\hline \multirow[b]{2}{*}{ 亭 } & \multirow[b]{2}{*}{ 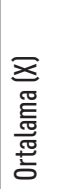 } & \multirow[b]{2}{*}{ 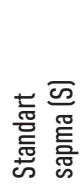 } & \multirow[b]{2}{*}{ 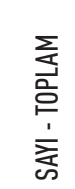 } & \multicolumn{4}{|c|}{ İdeolojik kimlikler konusunda görüșünüz nedir? (\%) } \\
\hline & & & & $\begin{array}{l}\text { Bana çok } \\
\text { uygun }\end{array}$ & Bana uygun & $\begin{array}{l}\text { Bana uygun } \\
\text { değil }\end{array}$ & $\begin{array}{l}\text { Bana hiç } \\
\text { uygun } \\
\text { değil }\end{array}$ \\
\hline Sosyal Demokrat & 2,388 & 8849 & $\begin{array}{l}5113 \\
\% 100\end{array}$ & 14,6 & 44,5 & 28,2 & 12,6 \\
\hline Liberal & 2,953 & 8208 & $\begin{array}{l}4642 \\
\% 100\end{array}$ & 4,5 & 22,5 & 46,0 & 26,9 \\
\hline Dindar & 2,091 & ,9357 & $\begin{array}{l}5178 \\
\% 100\end{array}$ & 29,1 & 43,3 & 17,1 & 10,5 \\
\hline Kemalist & 2,866 & 1,0238 & $\begin{array}{l}4937 \\
\% 100\end{array}$ & 14,5 & 16,5 & 36,9 & 32,1 \\
\hline Milliyetçi & 1,978 & 1,0185 & $\begin{array}{l}5179 \\
\% 100\end{array}$ & 39,1 & 37,8 & 9,2 & 13,8 \\
\hline
\end{tabular}


Tablo-6: Kimlikler Arası İlişkiler

\begin{tabular}{|c|c|c|c|c|c|c|}
\hline & & Sosyal Demokrat & Liberal & Dindar & Kemalist & Milliyetçi \\
\hline \multirow{3}{*}{$\begin{array}{l}\text { Sosyal } \\
\text { Demokrat }\end{array}$} & $\begin{array}{l}\text { Pearson } \\
\text { Correlation }\end{array}$ & 1 &, 312 & ,099 &, 206 &, 045 \\
\hline & $P$ & &, 000 & ,000 &, 000 & ,002 \\
\hline & $\mathrm{N}$ & 5113 & 4479 & 4875 & 4732 & 4883 \\
\hline \multirow{3}{*}{ Liberal } & $\begin{array}{l}\text { Pearson } \\
\text { Correlation }\end{array}$ & ,312 & 1 & ,073 & 243 &, 093 \\
\hline & $P$ & ,000 & & ,000 & ,000 & ,000 \\
\hline & $\mathrm{N}$ & 4479 & 4642 & 4536 & 4485 & 4538 \\
\hline \multirow{3}{*}{ Dindar } & $\begin{array}{l}\text { Pearson } \\
\text { Correlation }\end{array}$ & ,099 & ,073 & 1 & -112 & 007 \\
\hline & $P$ & ,000 & ,000 & & ,000 & ,000 \\
\hline & $\mathrm{N}$ & 4875 & 4536 & 5178 & 4838 & 4985 \\
\hline \multirow{3}{*}{ Kemalist } & $\begin{array}{l}\text { Pearson } \\
\text { Correlation }\end{array}$ & 206 & ,243 &,- 112 & 1 &, 245 \\
\hline & $\mathrm{P}$ &, 000 & 000 & ,000 & & ,000 \\
\hline & N & 4732 & 4485 & 4838 & 4937 & 4881 \\
\hline \multirow{3}{*}{ Milliyetçi } & $\begin{array}{l}\text { Pearson } \\
\text { Correlation }\end{array}$ &, 045 & ,093 & ,097 &, 245 & 1 \\
\hline & $P$ & ,000 &, 000 & ,000 &, 000 & \\
\hline & $\mathrm{N}$ & 4883 & 4538 & 4985 & 4881 & 5179 \\
\hline
\end{tabular}

Araştırmanın değişkeni durumunda olan kimlikler arasında istatistiksel açıdan anlamlı $(\mathrm{P}<0,05)$ ilişki olduğu tespit edilmiştir. Kimliklerin kendi aralarındaki ilişkinin korelasyon değerleri dikkate alındığında (Tablo-6), "Sosyal Demokrat", "Liberal", "Dindar", "Milliyetçi" kimliklerinden oluşan dört kimliğin arasında doğrusal bir ilişki bulunduğu anlaşılmaktadır. Bu dört kimlik arasında "Sosyal Demokrat-Liberal" $(0,312)$, "KemalistMilliyetçi" $(0,245)$, "Liberal-Kemalist" $(0,243)$ ve "Sosyal Demokrat-Kemalist" $(0,206)$ kimlik ikilileri arasında ise görece yüksek ilişki bulunduğu tespit edilmiştir. Buna karşılık, araştırmanın ilginç bir bulgusu olarak ifade etmek gerekirse, "Dindar" ile "Kemalist" kimliği arasında ters ilişki vardır $(0,112)$.

Yani "Dindar" kimliğinin kabullenilme oranı yükseldikçe "Kemalist" kimliğinin kabullenilme oranı düşmektedir. Veya "Dindar" kimliğinin kabullenilme oranı düştükçe "Kemalist" kimliğinin kabullenilme oranı yükselmektedir. Bu, "Dindar" ve "Kemalist" kimliklerinin birbirlerini "ötekileştirdiklerini” ifade etmesi; bu iki kimlik arasında birbirlerini ötekileştirme ilişkisi bulunduğunu göstermesi açısından manidardır. 
Tablo-7: Sosyal Medyaya Ilişkin Tutum ve Görüşler

\begin{tabular}{|c|c|c|c|c|c|c|c|}
\hline \multirow[b]{2}{*}{ 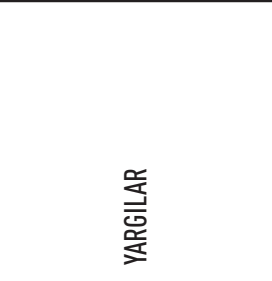 } & \multirow[b]{2}{*}{ 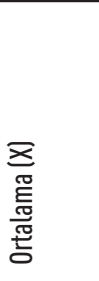 } & \multirow[b]{2}{*}{ 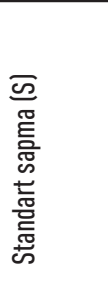 } & \multirow[b]{2}{*}{ 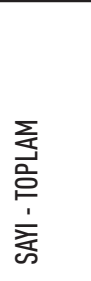 } & \multicolumn{4}{|c|}{$\begin{array}{c}\text { Sosyal medyaya ilișkin yargıya katılma biçiminiz } \\
\text { nedir? }[\%]\end{array}$} \\
\hline & & & & 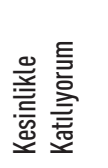 & 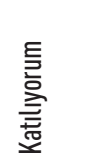 & 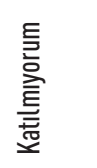 & 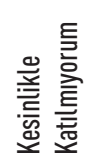 \\
\hline $\begin{array}{l}\text { “Sosyal medya yașam } \\
\text { tarzidır” }\end{array}$ & 2,975 & 8538 & $\begin{array}{r}5695 \\
\% 100\end{array}$ & 6,3 & 18,8 & 45,9 & 29,0 \\
\hline $\begin{array}{l}\text { “Sosyal medya hayatın } \\
\text { vazgeçilmez parçasıdır” }\end{array}$ & 2,956 & 8731 & $\begin{array}{l}5671 \\
\% 100\end{array}$ & 6,0 & 22,3 & 41,7 & 30,0 \\
\hline $\begin{array}{l}\text { “Sosyal medyasız hayat } \\
\text { boștur” }\end{array}$ & 3,109 & 8211 & $\begin{array}{r}5691 \\
\% 100\end{array}$ & 5,6 & 12,0 & 48,3 & 34,2 \\
\hline $\begin{array}{l}\text { “Sosyal medya } \\
\text { özgürlüktür” }\end{array}$ & 2,339 &, 8717 & $\begin{array}{r}5712 \\
\% 100\end{array}$ & 6,7 & 25,4 & 43,3 & 24,7 \\
\hline "Sosyal medya zararlıdır" & 2,859 &, 8648 & $\begin{array}{r}5674 \\
\% 100\end{array}$ & 17,0 & 41,9 & 31,4 & 9,8 \\
\hline
\end{tabular}

Araştırmanın birinci değişkenini ideolojik kimlikler, ikinci değişkenini ise sosyal medyaya ilişkin tutum ve anlayışlardır. Bu makale kapsamında, araştırmada yer almış olan beş soru, sosyal medya ile ilgili değişkenleri teşkil etmektedir. Bunlar katılımcılara yargı cümleleri biçiminde yöneltilmiş sorulardır. Katılımcı gençlerden bu yargı cümlelerine katılıp- katılmadıklarını belirtmeleri istenmiştir (Tablo-7). Bunlar sosyal medyanın önem ve işlevine ilişkin oluşturulmuş yargı cümleleridir. Söz konusu yargı cümleleri şunlardır: "Sosyal medya yaşam tarzıdır", "Sosyal medya hayatın vazgeçilmez parçasıdır", "Sosyal medyasız hayat boştur", "Sosyal medya özgürlüktür", "Sosyal medya zararlıdır".

Yargı cümlelerinden dört tanesi olumlu anlam ve işlevi kapsarken, bir tanesi olumsuz anlam ve işlevi kapsamaktadır. Araştırmanın örneklem grubunu teşkil eden gençlerin olumlu anlam ve işlevi dile getiren yargı cümlelerine ilişkin tutum ve düşünceleri dikkate alındığında, son derece ilginç ve manidar bir şekilde, gençlerin, gündelik hayatta gözlemlendiği kadarıyla gündelik hayatın vazgeçilmez unsuru haline gelmiş bulunan, hayatın her alanında yer edinmiş olan sosyal medyanın anlam ve işlevine ilişkin tutum ve görüşleri pek de olumlu değildir. Gündelik hayatta eğlencenin, bilgilenmenin, iletişimin, sosyal ilişki kurma ve geliştirmenin, resmi birçok işlemi yürütmenin aracı ve hatta en önemli aracı haline geldiği gözlemlenen sosyal medya, gençler tarafından düşünsel açıdan pek olumlu bulunmamaktadır. Yine gündelik hayatta gözlemlendiği kadarıyla, açıkça bir yaşam tarzı haline geldiği düşünülen ve görülen sosyal medyanın 
"yaşam tarzı olduğu" görüşü için gençler \%45'lik oranla "Katılmıyorum", \%29'luk oranla da "Kesinlikle katılmıyorum" demektedirler. Örneklem grubu teşkil eden gençlerin, sosyal medyanın "hayatın vazgeçilmez unsuru" olduğuna ilişkin yargı cümlesi karşısındaki tutum ve görüşler de benzerdir. Gençlerin \%41,7’i "Katılmıyorum", \%30'u ise "Kesinlikle katılmıyorum" cevabını vererek, sosyal medyanın "hayatın bir parçası olduğu" görüşünü reddetmişlerdir. Oranlar görece değişmekle birlikte "Sosyal medyasız hayat boştur", "Sosyal medya özgürlüktür" yargı cümleleri karşısındaki tutum ve görüşler de benzer durumdadır.

Tablo-8: Sosyal Medyaya İlişkin Tutum ve Görüşler Arası İlişkiler

\begin{tabular}{|c|c|c|c|c|c|c|}
\hline & & 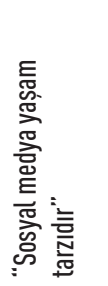 & 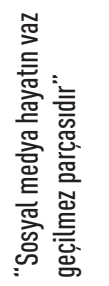 & 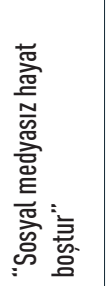 & 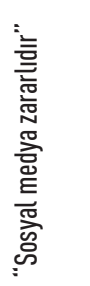 & 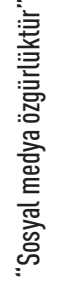 \\
\hline \multirow{3}{*}{ “Sosyal medya yașam tarzıdır” } & $\begin{array}{l}\text { Pearson } \\
\text { Correlation }\end{array}$ & 1 & ,745 & 668 &,- 079 &, 513 \\
\hline & $P$ & & ,000 & ,000 & ,000 & 000 \\
\hline & N & 5695 & 5645 & 5671 & 5643 & 5686 \\
\hline \multirow{3}{*}{$\begin{array}{l}\text { “Sosyal medya hayatın vaz } \\
\text { geçilmez parçasıdır” }\end{array}$} & $\begin{array}{l}\text { Pearson } \\
\text { Correlation }\end{array}$ &, 745 & 1 & ,728 &,- 059 & ,497 \\
\hline & $P$ &, 000 & & ,000 & ,000 & 000 \\
\hline & $\mathrm{N}$ & 5645 & 5671 & 5640 & 5622 & 5661 \\
\hline \multirow{3}{*}{ "Sosyal medyasız hayat boștur" } & $\begin{array}{l}\text { Pearson } \\
\text { Correlation }\end{array}$ & ,668 & ,728 & 1 &,- 060 & ,494 \\
\hline & $P$ & ,000 & 000 & & 000 & 000 \\
\hline & $\mathrm{N}$ & 5671 & 5640 & 5691 & 5641 & 5682 \\
\hline \multirow{3}{*}{ “Sosyal medya zararlıdır” } & $\begin{array}{l}\text { Pearson } \\
\text { Correlation }\end{array}$ &,- 079 &,- 059 &,- 060 & 1 &,- 051 \\
\hline & $P$ &, 000 & ,000 & ,000 & & 000 \\
\hline & $\mathrm{N}$ & 5643 & 5622 & 5641 & 5674 & 5658 \\
\hline \multirow{3}{*}{ “Sosyal medya özgürlüktür” } & $\begin{array}{l}\text { Pearson } \\
\text { Correlation }\end{array}$ &, 513 & ,497 & ,494 &,- 051 & 1 \\
\hline & $P$ & ,000 & 000 & ,000 & ,000 & \\
\hline & N & 5686 & 5661 & 5682 & 5658 & 5712 \\
\hline
\end{tabular}

Sosyal medyanın anlam ve işlevine ilişkin olumlu ve yüceltici anlayışlara itiraz eden gençler, sosyal medyanın "zararlı olduğu" görüşüne destek vermektedirler. Gençlerin 
\%41,9'u "Katılıyorum", \%17'si ise "Kesinlikle katılıyorum" cevapları ile veya aynı bağlamda anlam ifade eden bu iki cevabı birleştirerek ifade etmek gerekirse gençlerin $\% 58,9$ 'u sosyal medyayı "zararlı" bulmaktadır. Bu tutum, sosyal medyanın anlam ve işlevini olumlu bir şekilde dile getiren yargı cümlelerine karşı sahip olunan anlayış ve görüşle uyumludur. Ancak gündelik hayatta gözlemlenenler açısından son derece manidardır. Zira ifade edildiği üzere, gündelik hayatta gözlemlendiği kadarıyla özellikle gençler sosyal medyayı yoğun olarak kullanmaktadırlar. Gençler sosyal medyayı yoğun olarak kullanmaktadırlar, ancak araştırmamızın bulgularına yansıdığı üzere sosyal medyayı ağırlıklı olarak zararlı bulmaktadırlar. Araştırmamızın bu bulguları yapılmış başka araştırmaların bulgularıyla örtüşmektedir. Bunlardan birisi Metin'in üniversite öğrencileri bağlamında yaptığı araştırmadır. Metin'in araştırma bulgularına göre $(2014: 173,174)$, üniversite öğrencileri sosyal medyayı aile içi ilişkileri zayıflattığı ve eşler arasında kıskançlığı artırdığı için zararlı bulduklarını ifade etmişlerdir.

Konu bağlamında örnek olarak dikkate alınabilecek bir diğer araştırma ise Tuğlu'nun gerçekleştirdiği araştırmadır. Tuğlu'nun ortaokul öğrencileriyle gerçekleştirdiği araştırma bulgularına göre (2017: 42,43) araştırmanın katıımcıları sosyal medyayı derslerine, sosyal faaliyetlerine yeterince vakit ayırmaya engel olduğu ve arkadaşlarıyla birliktelik zamanını azalttığı için olumsuz değerlendirmişlerdir. Bu bulgulardan rahatlıkla gözlemlenebildiği üzere bir tutum karmaşası yaşanmaktadır. Söz konusu karmaşanın sebebinin ilginç ve başlı başına bir araştırma konusu olacak kadar önemli olduğu düşüncesindeyiz.

Araştırma sonucunda ulaşılmış çelişik durumu açıklayacak en iyi örnek gündelik yaşamda örneklerine sıklıkla rastlanan sigara kullanımı ile ilgili tutum ve davranışlar olabilir. Zira insanlar sigaranın birçok bakımdan zararını biliyorlar fakat buna rağmen isteyerek, severek veya hoşlanmasalar da içmeye devam etmektedirler. Hâlbuki olması gereken ya sigara hakkındaki tutum ve görüşleri değiştirmek, ya da sigara içmemektir. Teorik açıdan bu böyle ancak, hayatın içinde teori ile uygulama örtüşmüyor. Bunun sosyal medya için de geçerli olabileceği hem gündelik yaşam pratiklerinden anlaşılmakta ve hem de yapılmış bilimsel araştırmaların bulguları olarak tespit edilmiş bulunmaktadır. Andreassan (2012) ve Orzack'ın (2005) dikkat çektiği üzere, bireyler sosyal medya aracılığıyla haberleşme, eğlenme, bilgileneme gibi birçok ihtiyaçlarını karşılama imkânına kavuşmuş bulunuyorlar. Ancak bu "araç" örneğin aynı zamanda "bağımlılık" riski taşıyan bir araçtır.

"Bağımlılık" riski doğrudan veya dolaylı olarak uyku bozukluklarına veya omuz, el-kol ağrıları gibi fiziksel rahatsızlıklar gibi problemlere yol açmakta veya bu tür problemlerin yaygınlık kazanmasına etki etmektedir. Yine Christakis ve Fowler'ın (2012) özellikle dikkat çektiği üzere, kişiden kişiye yayılanlar sadece bireyi hasta eden virüsler değil, aynı zamanda bazı davranışlardır. Davranış taklitleri, yeme-içme davranışlarındaki, vakti değerlendirme tutumlarındaki, yaşamı planlama eğilimlerindeki yanlışlıkların sebebi olabilmektedir. Bu açıdan sosyal medya önemli bir araç olarak işlev görebilmekte; bireyler kolaylıkla yanlış tutum ve anlayışlara kendilerini kaptırabilmektedirler. Bunlar, literatürde yer alan biçimiyle, sosyal medyaya ilişkin ikircikli tutum ve davranışların 
sebep ve biçimlerinden sadece bazılarıdır. Dolayısıyla, araştırmamızın bir bulgusu olarak ifade etmemiz gerekirse, gençler sosyal medyayı yüceltmiyorlar, kayda değer bir değer atfetmiyorlar; hatta "zararlı" olduğun düşünüyorlar ancak buna rağmen yoğun bir şekilde kullanmaya devam ediyorlar.

Gençlerin sosyal medyanın önem ve işlevine ilişkin tutum ve görüşleri, sosyal medya bağlamında kendilerine yöneltilmiş tutum sorularına verdikleri cevapların frekans değerleri dikkate alınarak inceleyecek olunursa (Tablo-7); sosyal medyanın anlam ve işlevine ilişkin olumlu yargı cümlelerine verilen cevaplar arasında doğrusal bir ilişki bulunduğu anlaşılmaktadır. Verilerin standart sapma değerleri dikkate alındığında katılımcı gençlerin görece homojen sayılabilecek bir tutum duruş sergiledikleri anlayış "Sosyal medyasız hayat boştur" görüşü ile ilgilidir. Ancak diğer görüşler karşısındaki tutumlar da "Sosyal medyasız hayat boştur" görüşün karşısındaki duruştan çok ayrık değildir. Zira sosyal medya ile ilgili anlayıșlarla ilgili tutumların standart sapma değerleri 0,8211 ile 0,8717 arasında yer almaktadır. Dolayısıyla homojen olup olmama açısından ayrışmanın görece düşük olduğu rahatlıkla ifade edilebilir.

Söz konusu verilerin ortalama değerleri de büyük oranda benzer noktayı işaretlemektedir; "Sosyal medyasız hayat boştur" cevabı hariç diğer görüşlerde hesaplanan ortalama "Katılmıyorum" cevabını işaretlemektedir. Ancak "Sosyal medyasız hayat boştur" görüşünün ortalaması da ötekilerden çok ayrık bir noktada değildir; "Kesinlikle katılmıyorum" cevabının "Katılmıyorum" cevabına yakın bir düzeyini işaretlemektedir. Genel bir değerleme yapmak gerekirse, gençlerin sosyal medyanın önem ve anlamına ilişkin anlayış ve yaklaşımlarda zihinsel bir kargaşa içerisinde olduğu ifade edilebilir.

Sosyal medyanın önem ve anlamına ilişkin görüş ve yaklaşımların birbirleriyle olan ilişkileri arasında istatistiksel açından anlamlı bir ilişki bulunmakta olup $(P<0,05)$, üstelik korelasyon değerleri görece yüksektir (Tablo-8). Tutum ve görüşlere yansıdığı üzere sosyal medyanın önem ve işlevine ilişkin olumlu yargı cümleleri ile sosyal medyanın "zararlı" olduğuna ilişkin yargı cümlesine karşı sahip olunan tutum ve anlayışlar arasında ise ters ilişki vardır. Yani bir tarafın kabullenilme durumu artarken diğer taraf düşmektedir. Bu bakımdan araştırmanın örneklem grubunu teşkil eden katılımcı gençler, sosyal medyanın önem ve anlamı konusunda kendi içlerinde tutarlı bir tutuma ve anlayışa sahip olduklarını ortaya koymuşlardır. 
Tablo-9: Kimlikler ile Sosyal Medyaya Illişkin Tutum ve Görüşler Arası Ilişkiler

\begin{tabular}{|c|c|c|c|c|c|c|}
\hline & & 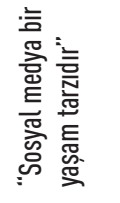 & 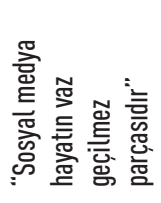 & 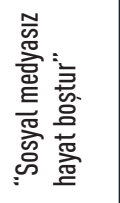 & 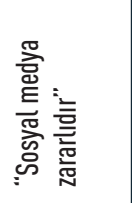 & 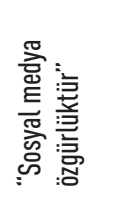 \\
\hline \multirow{3}{*}{ Liberal } & $\begin{array}{l}\text { Pearson } \\
\text { Correlation }\end{array}$ & ,058 & ,072 & ,069 & $-0,020$ & 110 \\
\hline & $P$ & ,000 & ,000 & ,000 & ,001 &, 000 \\
\hline & $\mathrm{N}$ & 4597 & 4584 & 4592 & 4575 & 4605 \\
\hline \multirow{3}{*}{ Sosyal Demokrat } & $\begin{array}{l}\text { Pearson } \\
\text { Correlation }\end{array}$ & ,034 & ,032 & 0,011 & ,030 & ,070 \\
\hline & $\mathrm{P}$ & ,000 & ,000 & ,000 & ,000 & ,000 \\
\hline & $\mathrm{N}$ & 5049 & 5035 & 5045 & 5039 & 5064 \\
\hline \multirow{3}{*}{ Dindar } & $\begin{array}{l}\text { Pearson } \\
\text { Correlation }\end{array}$ &,- 084 &,- 094 &,- 084 &, 069 &,- 149 \\
\hline & $P$ & ,002 &, 002 & ,002 & ,000 & 012 \\
\hline & $\mathrm{N}$ & 5127 & 5101 & 5121 & 5098 & 5136 \\
\hline \multirow{3}{*}{ Kemalist } & $\begin{array}{l}\text { Pearson } \\
\text { Correlation }\end{array}$ & ,075 & ,115 & ,113 &,- 056 &, 169 \\
\hline & $\mathrm{P}$ &, 000 &, 000 &, 000 & ,001 &, 000 \\
\hline & $N$ & 4887 & 4867 & 4883 & 4863 & 4895 \\
\hline \multirow{3}{*}{ Milliyetçi } & $\begin{array}{l}\text { Pearson } \\
\text { Correlation }\end{array}$ & ,034 & ,050 & ,038 & 0,016 & ,052 \\
\hline & $P$ & ,000 & ,000 & ,000 & ,000 &, 000 \\
\hline & $\mathrm{N}$ & 5124 & 5105 & 5122 & 5100 & 5136 \\
\hline
\end{tabular}

Araştırmanın asıl konusunu ideolojik kimlikler ile sosyal medyanın anlam ve işlevine ilişkin sahip olunan tutum ve anlayışlar arasındaki bir ilişkinin olup-olmadığını, eğer varsa söz konusu ilişkinin gücünü ve yönünü tespit etmek oluşturmaktadır. Bu sebeple araştırma kapsamında yer alan ideolojik kimlikler açısından sosyal medyanın anlam ve işlevine ilişkin ifade edilen görüşler arasındaki ilişki istatistiksel açıdan incelendi (Tablo-9).

Ulaşılan sonuçları her bir kimlik açısından ayrı ayrı ifade etmek gerekirse, kimlikler ile sosyal medyaya ilişkin tutum ve görüşler arasında istatistiksel açısında anlamlı bir ilişki bulunduğu tespit edilmiştir $(P<0,05)$. Tespit edilen ilişkiyi kimlikler bağlamında incelemek gerekirse; "Liberal" kimliği ile sosyal medyanın "yaşam tarzı", "hayatın vaz geçilmez parçası", "özgürlük" olarak nitelendiği yargı cümleleri ile "sosyal medyasız bir hayat boştur” yargı cümlesine katılma biçimleri arasında doğrusal bir ilişki bulunduğu 
gözlenmektedir. Beklentiye uygun olarak da sosyal medyanın "zararlı" olduğu görüşü ile "Liberal" kimliği arasında ters ilişki vardır. "Kemalist" kimliği ile sosyal medyanın anlam ve işlevine iliş̧kin tutum ve görüşler arasındaki ilişki "Liberal” kimliğindeki gibidir. $\mathrm{Bu}$ iki kimlik açısından sosyal medyanın anlam ve işlevine ilişkin tutum ve görüşler benzeşmektedir. Illginç bir bulgu olarak ifade etmek gerekirse, "Sosyal Demokrat" kimliği ile sosyal medyanın anlam ve işlevine ilişkin tutum ve görüşlerin hem olumlu olanları ve hem de olumsuz olanı arasında doğrusal bir ilişki vardır.

"Sosyal Demokrat” kimliği ile sosyal medyanın "zararlı" olduğu görüşü arasındaki ilişkinin doğrusal olması oldukça manidardır. Benzer durum "Milliyetçi" kimliğinde de gözlenmektedir. Kimlikler arasında farklı ve oldukça ilginç durum "Dindar" kimliğinde gözlenmektedir.

"Dindar" kimliği ile sosyal medyanın anlam ve işlevine ilişkin olumlu yargı cümleleri arasında ters ilişki, sosyal medyanın "zararlı" olduğuna ilişkin yargı cümlesi arasında düz ilişki vardır. Anlaşıldığı kadarıyla "Dindar" kimliğine mensup olanlar sosyal medya karşısında diğer tüm ideolojik kimlik mensuplarına göre oldukça farklı bir tutum ve görüşe sahiptirler.

\section{Sonuç}

Kimlik tanımlar; tanımlarken tanımladığını "öteki”lerden ayırarak ve anlam alanında yer alan özellikleri bir araya toplayarak yapar. Böylelikle bir özne inşa eder ve/ veya bir özneye işaret eder. Kimlik çoktur; dolayısıyla özne çoktur. Birey açısından düşünüldüğünde, birey cinsiyetiyle "er", toplumsal cinsiyetiyle "erkek", mesleği ile "marangoz", etnik kimliği ile "Türk", dini ile "Müslüman", mezhebi ile "Hanefi", ideolojisi ile "Demokrat"... kimliklerine sahip olabilir.

Bu kimliklerin bazıları dikey olarak birbirini kapsayacak şekilde sıralanırken (MüslümanSünni-Hanefi), bazısı ise yatay olarak birbirinden ayrık bir şekilde (Erkek- MarangozTürk) sıralanırlar. Kimlik birçok işlevi yerine getirir. En önemlisi, öznesinin olay ve olgular karşısındaki durumunu belirler veya işaret eder. Dolayısıyla bir kişinin veya toplum kesiminin kimliği, o kimlik bağlamında bir durum veya olaya karşı ne tür tutum veya davranışa sahip olunduğunu veya olunacağını ifade etmiş olur. Bu bakımdan makalenin de konusu olan ideolojik kimler önemlidir.

Örneğin bir "Sosyalistin" veya "Kapitalistin" para, ticaret, kâr anlayışları, hukukun kaynağına ve misyonunu ilişkin görüşleri birbirlerinde çok farklıdır; daha doğrusu farklı olması beklenir. Çünkü bu iki ideolojinin referansları, beklentileri, anlamlandırma biçimleri ve sıralamaları birbirinden çok farklıdır. Böyle olunca, günümüzün önemli bir olgusu haline gelmiş bulunan sosyal medyanın anlam ve işlevine ilişkin görüşlerin de farklı ideolojiler açısından farklılaşması beklenir. Acaba öyle mi? Bunu tespit etmek için referansları, değerler sistemi ve misyonları birbirinden ayrı beş ayrı ideoloji bağlamında sosyal medyanın anlam ve işlevine iliş̧in tutum ve anlayışları inceledik. 
Araştırmamızın değişkeni konumunda olan ideolojiler "Liberal", "Sosyal Demokrat, "Dindar", "Kemalist" ve "Milliyetçi" ideolojileridir. Bu beş ideolojinin birbirleriyle olan ilişki durumları incelendiğinde en önemli ayrışmanın "Kemalist" ve "Dindar" kimlikleri arasında olduğu ve bunların birbirlerini belirli oranda da olsa ötekileştirdikleri tespit edilmiştir. Beş ideolojinin diğer bakımlardan birbirlerinden ayrışmaları daha çok eksik girişimlilik biçiminde olduğu; yani aralarında anlam örtüşmeleri olduğu gözlenmiştir. Benzer inceleme sosyal medyanın anlam ve işlevine ilişkin görüşler arasında yapıldığında sosyal medyayı olumlu bulan anlayışlar birbirleriyle örtüşen bir benzerlik içerisinde bulunurlarken, sosyal medyayı "zararı" bulan görüşün ayrıştığı tespit edilmiştir. Kimlikler ile sosyal medyanın anlam ve önemine ilişkin tutum ve görüşler arası ilişki incelendiğinde, en önemi ayrışmanın "Dindar" kimliğinde olduğu; "Dindar" kimliği ile sosyal medyayı olumlu bulan anlayışlar arasında ters, sosyal medyayı "zararlı" bulan anlayış arasında düz ilişki bulunduğu tespit edilmiştir.

\section{Kaynakça}

Andreassen, C. S., (2012). "Development of a Facebook Addiction Scale", Psychological Reports, 110 (2).

Castells, M. (2013). Communication Power, Oxferd University Press, Oxford.

Christakis, N. A.; Fowler, J. H., (2012). Sosyal Ağların Şaşırtıcı Gücü ve Yaşantımızı

Biçimlendiren Etkisi, Varlık Yayınları, İstanbul.

Kazancı, M. (2003). "Althusser ide İdeoloji Üzerine Yapılamamış Bir Söyleşi”, İletişim Araştırmaları, 1(2).

Mardin, Ş., (1982). İdeoloji, Turhan Kitapevi, Ankara.

Metin, O., (2014), Sosyal Medyanın Siyasal toplumsallaşmaya Etkileri: Üniversite Öğrencileri Örneği, Afyon Kocatepe Üniversitesi, Doktora tezi, Afyon Kocatepe.

Orzack, M. H., (2005). Bilgisayar Bağımlılığı, http://www.compoteraddiction.com, (Erişim: 5 Ekim 2018).

Outhwaite, William, (2008). Modern Toplumsal Düşünce Sözlüğü, (Çev.) Pekdemir, M., İletişim Yayınları, İstanbul.

Özbek, S. (2011). İdeoloji Kuramları, Notos Yayınları, İstanbul.

Poytner, R., (2010). The Handbook of Online and Social Research, West Sussex.

Purvis, T. (2014). "Söylem, İdeoloji”, Hacettepe Üniversitesi Illetişim Bilimleri Fakültesi Kültürel Çalışmalar Dergisi, 1(1).

Safko, L., (2010). The Social Media Bible, New Jersey.

Scott, D.M., (2010). The New Rules of Marketing and PR, New Jersey.

SEKAM, (2013). Türkiye'de Gençlik (Gençliğin Özellikleri, Sorunları, Kimlikleri ve Beklentileri), SEKAM Yayınları, İstanbul. 
Tuğlu, B. (2017), Ortaokul Öğrencilerinin Sosyal Medyayı Kullanım Amaçları Ve Sosyal Medya Kullanımlarına Iliş̧kin Tutumları, Sakarya Üniversitesi, Yüksek Lisans Tezi, Sakarya.

Vatandaş, C. (2010). Ulusal Kimlik, Açılımkitap Yayınları, İstanbul.

Vatandaş, S. (2015). "Sosyal Medyanın Anlam ve Öneminin Cinsiyetler Bağlamında İncelenmesi", Uluslararası Yönetim ve Sosyal Araştırmalar Dergisi, 1(2).

Zarella, D., (2010). The Social Media Marketing Book, O’Reilly, Canada. 